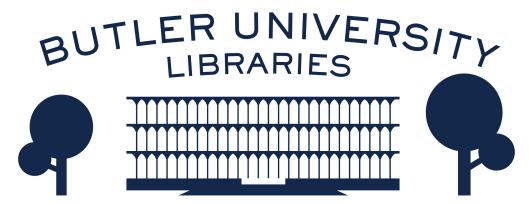

Journal of Hindu-Christian Studies

\title{
Book Review: "Annam Bahu Kurvita: Recollecting the Indian Discipline of Growing and Sharing Food in Plenty"
}

Anand Amaladass

Follow this and additional works at: https://digitalcommons.butler.edu/jhcs

Part of the Religion Commons

\section{Recommended Citation}

Amaladass, Anand (1998) "Book Review: "Annam Bahu Kurvita: Recollecting the Indian Discipline of Growing and Sharing Food in Plenty"," Journal of Hindu-Christian Studies: Vol. 11, Article 21.

Available at: https://doi.org/10.7825/2164-6279.1194

The Journal of Hindu-Christian Studies is a publication of the Society for Hindu-Christian Studies. The digital version is made available by Digital Commons @ Butler University. For questions about the Journal or the Society, please contact cbauman@butler.edu. For more information about Digital Commons @ Butler University, please contact digitalscholarship@butler.edu. 
impact, what is its extent, what are the reasons for it, and when did Indian thought come in contact with Israel, Greece, and Rome in ancient times to impress its thoughts upon the development of early Christian thought?

Instead of carefully weighing the evidence considered by him to be crucial to support his claims, the author makes unsupported pronouncements from the very beginning. The basic argument of the book is that any philosophical idea, religious notion, ethical ideal, or ritual practice found in the Judeo-Christian literature that is even remotely parallel to similar elements in Hinduism or Buddhism must have its source in some direct or indirect impact of ancient Indian thought on Jewish-Christian heritage during its formative period. However, a reader looking for specific historical or textual evidence to support this initial provocative thesis will find only possibilities, conjectures, and hypotheses which the author never succeeds in translating into definitive conclusions based on scholarly analysis of the material studied. Although Deshpande discovers some interesting resemblances between Christianity and ancient Indian thought, any value of this book as a comparative study is severely compromised by the author's categorical statement that if we find any resemblance between ancient Indian metaphysical thought and that of Christian scriptures "it will be logically concluded that such resemblance is due to the impact of ancient Indian thought on Christianity..." (p.79).

The book nevertheless does have a semblance of solid scholarly work and there are valuable insights into the possibilities of cross fertilization of ideas between India and the near East. There are detailed time lines, lists of documents, comparative charts, an appendix, and an impressive bibliography. Discussions of thematic affinities between ancient Indian thought and the Biblical tradition is definitely interesting and in some ways refreshing. The major flaw of Deshpande's book, however, is that thematic and structural affinities in the two major cradles of ancient civilization are presumed to be causally related, with a clear bias toward asserting both the chronological and ideological superiority of ancient Indian thought over the Biblical tradition, which is supposed to have been impacted in every possible way by Indian thought.

Braj M. Sinha

University of Saskatchewan

\section{Annaì Bahu Kurvita: Recollecting the Indian Discipline of Growing and Sharing Food in Plenty. Jitendra Bajaj and Mandayam Doddamane Srinivas. Madras: Centre for Policy Studies, 1996, lvi +217 pp.}

THIS BOOK WAS written with a purpose. As the title indicates, the theme is the Indian discipline of growing and sharing food in plenty. That is not "a question merely of economics, but of the essence of dharmic living" (p.xii). It is said that the inviolable discipline of sharing is what defines the essence of being Indian (p.210). At a time when people begin to reflect what it is to be
Indian and come out with different theories, this book highlights another dimension to this question of Indianness.

What is presented in this book is not a social analysis of the Indian situation, giving statistics of people living below the poverty line or the factors contributing to this situation. The emphasis is on the aspect of sharing with others. The authors establish 
from different ancient texts and inscriptional evidence how our ancestors have practised the discipline of growing and sharing in abundances for ages. It is in fact a good source book on this theme - with Sanskrit text and English translation.

The intention of this book is to draw the attention of the readers to a noble practice of sharing with others, and thus building a community of love and concern. This is said to be the characteristic of Indian civilization. In fact, the Bhagavad Gita calls a person a thief if he cooks food only for himself, with no intention of sharing with others (p.3, 12). If this idea is taken seriously and people live up to it, the situation in India will be different.

But then, why is that such noble thoughts are ignored, or at least not practised by people in India? The authors assert that it was the onslaught of the British that brought about this decline in dharmic living. Deprecating the Indian manners, as in the book of Abbe Dubois, the British administrators expressed antipathy towards Indian ways, thereby disrupting the polity, as evidenced by the writings of Richard Welleseley (Governor General in Mysore, (p. 195), and polluting the minds of the
Indians. This has gradually brought about the callousness which is almost institutionalized in Indian society.

That colonial rule in India had its negative impact is not to be denied. But to draw the conclusion from this that the present situation of poverty and hunger and the people's attitude of looking to one's own benefit and that of one's ethnic community is the result of colonial rule sounds rather naive. It is true the colonizers everywhere had their profit motive and displayed a superiority complex. But that does not explain the present-day callousness of Indian people and all that is happening in the socioeconomic-political situation. The issue is complex, involving many factors. And we should take responsibility for the present situation in India and work for a change of attitude among the people.

However, the book is a valuable source of information concerning the practice of sharing in Indian culture that needs to be brought to the awareness of people so that they begin to see the abiding significance of such an Indian cultural value.

Anand Amaladass, S.J. Madras

\section{Mysticism in Shaivism and Christianity. Bettina Bäumer, Ed. New} Delhi: D.K. Printworld Ltd., 1997. xviii + 365 pp.

THE BOOK UNDER review is the result of a seminar organized as a spiritual dialogue between the Shaivas and the Christians in 1990 under the auspices of the Abhishiktananda Society. The first article by Alois Hass was later added to this volume in order to clarify the very concept of mysticism. As it stands, there are seven entries from the Christian side and five from Shaiva perspectives.

The enlarged version of Raimon Panikkar on the mysticism of Jesus Christ includes the historical perspective before presenting a few select Mahavakyas of Christ with an "intercultural exegesis". There is one presentation on Mysticism of Shaiva Siddanta by Swami Nityanandagiri and three entries on Kashmor Saivism (H.C. Chakravarty, B. N. Pandit and J. N. Kaul).

Among the Christian mystics Meister Eckhart (Sr Brigitte), Hadewijck (O. Baumer-Despeigne), Julian of Norwich (Murray Rogers), and Ignatius of Loyola (G. Gispert-Sauch) are discussed in this volume. 